\title{
Congenital Neurogenic Bladder
}

National Cancer Institute

\section{Source}

National Cancer Institute. Congenital Neurogenic Bladder. NCI Thesaurus. Code

C123205.

Neurogenic bladder, the cause of which is present at birth. 